\title{
The proposition of utilisation the vehicle in 1:5 scale to construction and testing of an autonomous vehicle
}

In the near future, vehicles will be moving autonomously with little participation or completely without the driver affecting on the vehicle move. Task of driver will be limited to identify the end point of the vehicle route. Vehicles, to meet this challenge, must be equipped with the control systems and supervising the movement of the vehicle, reacting onto the movement of pedestrians and other vehicles, road signs, time of day and weather conditions. The movement of the vehicle will be controlled and driven by a system on board a vehicle, but will also be required to tracking the vehicles position and its movement parameters using of the vehicle satellite navigation systems. In addition, the motion trajectory of the vehicle will be determined and any deviation from the target track will be corrected.

The article presents a proposal for determining the trajectory of the vehicle based on the control points specified by the coordinates of the location of the vehicle and ways of correcting the trajectory of the vehicle. For this purpose was utilized the vehicle in scale.

Key words: autonomous vehicle, determining the trajectory of the vehicle, the correction of the vehicle motion trajectory

\section{Introduction}

The main task of the autonomous vehicle is to carry passengers and cargo from a specific starting place to the particular ending position. In addition, the vehicle must react to the situation on the road, pedestrians, vehicles and road signs. This vehicle also must adjust their speed to the road conditions, speed up or slow down and to keep in their road lane. These properties require the development of an autonomous vehicle control system that is able to respond to traffic conditions in every situation by adjusting the speed and direction of vehicle motion. For this reason, the control of the autonomous vehicle is a complex issues, which consists of a number of different tasks. These tasks can be analysed and implemented separately.

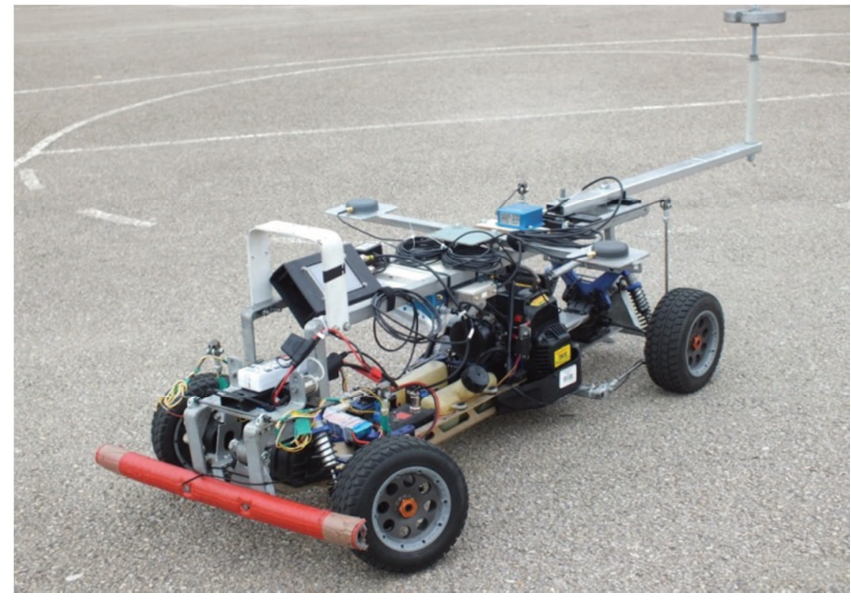

Fig. 1. The measurement equipment mounted on the vehicle in scale

In the Department of Internal Combustion Engines and Vehicles of University of Bielsko-Biala was built vehicle in a scale of 1: 5, which has been used to study the vehicles stability. For this purpose, was used the theory of similarity and $\pi$-theorem of Buckingham [3,5]. To describe the parameters of the vehicle and its movement were used the dimensionless variables, normalized using the basic units like: length, mass and time.
Presented vehicle in scale, in addition to the requirements such as the maintenance of conditions similarity to the full size vehicle (geometric, kinematic, dynamic and structural similarities), the behavior of the similarity of the test research, was designed to drive defined route with a defined speed. From these tasks we saw that is required to build a specific control system for our vehicle. This system will could control the vehicle motion, to ride vehicle in scale after a certain, imposed from the top track and be able to make adjustments to the realized trajectory of motion. In addition to the evaluation parameters of vehicle movement was necessary to select of the measuring equipment with low weight and small size while maintaining the required measurement accuracy.

\subsection{Description of the vehicle in scale}

For the build of the vehicle in scale was used an existing radio controlled vehicle in scale 1:5, Himoto Raptor, which was modified resulting from the need to meet the requirements of similarity to the full-size vehicle.

The vehicle in scale it was equipped with an internal combustion engine with a capacity of $26 \mathrm{ccm}$, centrifugal clutch, gearbox, powertrain with central gear and differentials on front and rear axle in the basic version. The driving torque is transmitted via a shaft to the gearbox and then through the shafts to front and rear differentials and through driveshaft on the wheel. Wheels consist of the rim of the plastic and rubber tires with stiffening inserts. The frame was made of aluminum sheet metal profiled, reinforced in the rear part. The basic version of vehicle has allowed riding with maximum speed of $70 \mathrm{kph}$. Suspension both front and rear are based on two wishbones with coil springs. The brake is mounted on the output shaft of the motor in the form of a single disk-compressible during braking. Servo motor controls the engine speed and brakes. The second servo motor is used to control of the steering system, it is connected to the longitudinal steering rod. The vehicle is controlled by radio (Fig. 1).

In order to maintain the conditions of similarity with respect to the full-size vehicle (the truck with a high-lying center of mass), it was done a number of modifications on 
the vehicle in scale. These modifications has included: increasing the wheelbase, change the position of the center of mass, changes the mass moments of inertia, changes the suspension of both the front and the rear axle from the independent to dependent, changing tires with characteristics similar to use in the real vehicle. Description of the vehicle after these modifications and methodology of conduct found in $[10,11,14,16]$. This vehicle was equipped with measuring apparatus Racelogic VBOX with module IMU and two antennas GPS/GLONAS.

The basis of the analysis was to use a model of the human driver that allows to achieve the desired action.

\section{The models of human driver}

In literature we can find models the human driver with a high complexity, allowing the inclusion of driver reaction time, delays resulting from the reaction of vehicle systems or correction of the track resulting from the nature of cooperation of tires with the road [7-9]. The following is the relationship describing the general model of the human driver [1].

$$
H(s)=h\left(\tau_{D} \cdot s+1+\frac{1}{\tau_{I} \cdot s}\right) \cdot e^{-\tau_{L} \cdot s}
$$

where: $\mathrm{h}-$ constant of proportionality, $\tau_{\mathrm{L}}-$ driver's reaction time, $\tau_{\mathrm{D}}-$ differentiation time constant, $\tau_{\mathrm{I}}-$ integration time.

In this study, we focused on passing the points lying on the track of the vehicle in scale and a possible correction of the assumed trajectory. For this purpose were used simpler models of human driver: a compensation [15], and anticipatory model $[1,6,13]$.

\subsection{The compensation model of human driver}

The compensating models of human drivers are relatively simple. The aim of their activities is to minimize the deviation of the position of the vehicle from the established track. In this model, the task of the human driver is the correction of the position of the car, which would lead to driving on the specified path. The basic equation describing the control of the vehicle can be presented in a form that allows the selection of the angle of rotation of the steering wheel [16]:

$$
\alpha(t)=P_{y} \cdot y(t)+P_{\alpha} \cdot \alpha_{0}(t)
$$

where: $\mathrm{P}_{\mathrm{y}}$ and $\mathrm{P}_{\alpha}-$ amplification factors of the human driver model, defining the sensitivity of the model to the lateral and angular deviation, $\alpha_{0}-$ the current angle of deviation the car from the predetermined direction, $\mathrm{y}(\mathrm{t})-$ the current value of the coordinate describing the lateral deviation of the vehicle from the predetermined direction.

\subsection{The anticipatory model of human driver}

The anticipatory model of human driver is based on the assumption that the driver observes the road some distance ahead of the vehicle $\mathrm{L}(\mathrm{m})$ and evaluates the deviation of lateral position of the vehicle from the established route $\varepsilon$ (Fig. 1, 2) [1, 6, 13].

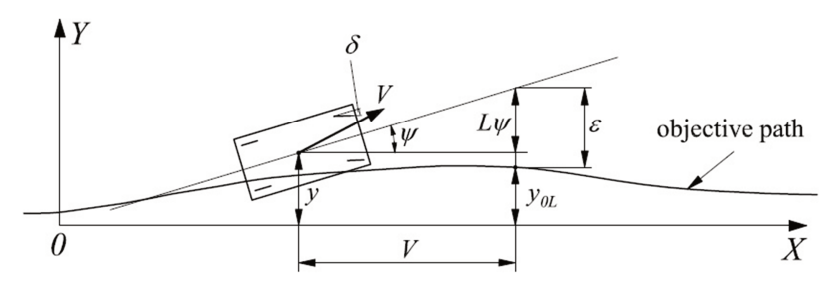

Fig. 2. The motion of the vehicle using of the anticipatory driver model

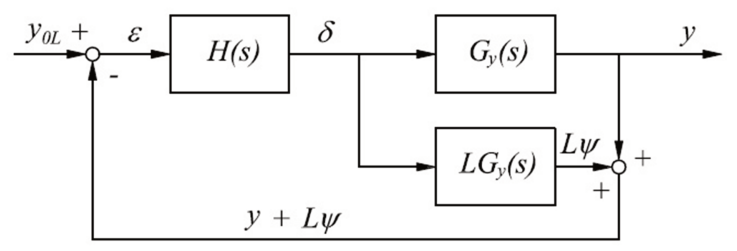

Fig. 3. The simple block diagram of a driver-vehicle system [1]

The estimated lateral displacement of the transverse component $\mathrm{y}_{0 \mathrm{~L}}$ is the distance traveled by the vehicle at time $\mathrm{t}=\mathrm{L} / \mathrm{V}$ in certain traffic conditions. Hence the mathematical description of the human driver model:

$$
\begin{gathered}
\alpha(\mathrm{t})=\mathrm{P} \cdot \beta\left(\mathrm{t}-\mathrm{t}_{\mathrm{R}}\right) \\
\varepsilon=\mathrm{y}+\mathrm{L} \beta-\mathrm{y}_{0 \mathrm{~L}} \\
\beta(\mathrm{t})=\frac{1}{\mathrm{~L}}\left[\varepsilon-\left(\mathrm{y}-\mathrm{y}_{\mathrm{OL}}\right)\right]-\alpha_{0}
\end{gathered}
$$

Reński [11] proposes the following solution to the problem presented above:

$$
\begin{aligned}
& \alpha(t)=\frac{P}{L} \cdot \varepsilon \cdot\left(t+\frac{L}{V}-t_{R}\right)- \\
& \frac{P}{L} \cdot\left(y-y_{O L}\right)\left(t-t_{R}\right)-P \cdot \alpha_{0} \cdot\left(t-t_{R}\right)
\end{aligned}
$$

where: $\mathrm{P}$ - amplification factors of the human driver model, $t_{R}-$ driver's and steering system reaction time, $\beta$ - angle between the longitudinal axis of the vehicle and the position of the point of observation, $y-$ the vehicle's position in the global coordinate system, $\mathrm{y}_{0 \mathrm{~L}}$ - estimated position of the vehicle (at the point of observation) after adjustment driving path, $\varepsilon$ - estimated lateral displacement of the vehicle at the point of observation $\mathrm{L}, \alpha_{0}-$ angle of longitudinal axis of the vehicle from the direction of the track, $\alpha$ - required steering angle, $\mathrm{L}$ - distance of the point of observation.

\section{Controlling of the vehicle in scale}

To drive was used the specially built system consisting of a microprocessor controller and servomotors. In the memory of controller was stored setting of servomotor to carburetor throttle and clamping the braking system and also servomotor to control of turning wheel angles. They have been saved the procedures specifying how to accelerate and stop the vehicle. In the memory of the controller has been saved also procedures to control the speed and direction of travel of the vehicle during the test. These proce- 
dures are similar to ISO tests but they have adapted to the size and speed of the vehicle in scale. Were made the location system of the vehicle utilizing the vehicle positioning system GPS assisted by the accelerometers and magnetometers to the realization driving after a specified path. In the first version of the system was used microcontroller Arduino II [4]. The proposed system allow for the ride of the vehicle after a predetermined track only at relatively low speeds.

\section{Tests of the vehicle in scale}

The application of the model the human driver to control of the vehicle in scale resulted from the vehicle path deviation of movement from the established track. This was due to disruptions caused by unevenness of the track, by various coefficient of adhesion of the driving wheels, by external forces as well as the phenomena occurring during twist maneuvers, such as: changing of load on left and right side of the vehicle, changing the suspension geometry, or the characteristics of the tires.

In the case where the direction of motion of the vehicle is affected by interference the external, a correction needs to establish of the position of the vehicle and its direction of movement. Under the direction of $\mathrm{K}$. Romaniszyn was developed controller equipped with a GPS chip, allowing the collection of information on the position and direction of the vehicle motion [3]. Efforts were made to use the compensating model of the human driver and ultimately create a system of autonomous control the direction of the vehicle movement.

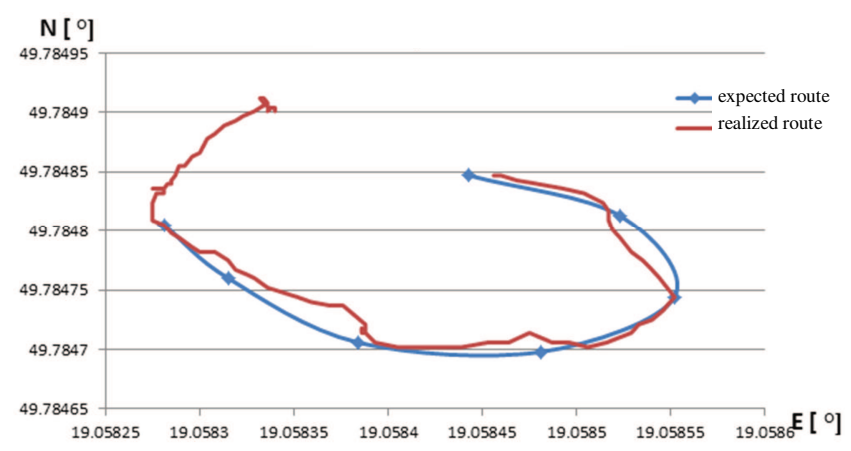

Fig. 4. Comparison of the preset and has made track of the vehicle physical model [3]

For this purpose was used the Arduino microcontroller, GPS antenna, and a number of actuators allowing for "programming" the trajectory of the vehicle by determining the selected waypoints. These selected points, have been achieved by the vehicle with the specified accuracy. The correction of the vehicle path was carried out by changing the twist angle of the steered wheels. Figure 4 shows the "programmed" and the real path of the vehicle in scale during test "ride the circular path".

The use of anticipatory model of human driver, presented in the work of M. Abe [1] requires the determination of the characteristics of tires, longitudinal and lateral speed of vehicle, center of mass, yaw ratio and twist angle of the steered wheels. During road tests of the vehicle in scale was used testing equipment of Racelogic VBOX 3i. This equipment allows for measurement of the position of the vehicle, its speed and direction of movement. Since the measured variables are required to determine the amendments of the wheel steer angle, based on the anticipatory model of human driver it is possible to make adjustments to the path of vehicle. Ongoing works allow determining the adjustment of the vehicle path. A simulation was performed using the results of measurements of the motion of the vehicle while driving along a circular path. Figure 5 shows the difference between the predetermined and realized radius of driving, during the test "ride on a circular path".

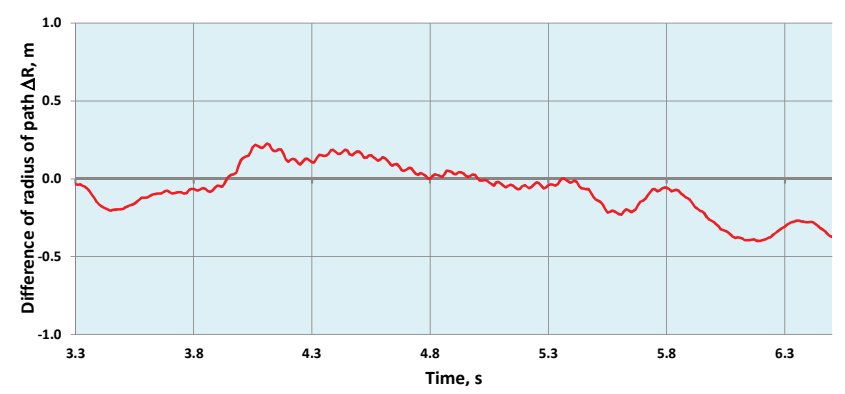

Fig. 5. The difference between predetermined and realized radius of driving, during the test "ride on a circular path"

Based on these graphs, you can attempt to make a correction of angle $\delta_{\mathrm{e}}$. this correction will be introduced with a delay resulting from the characteristics of the control system of the vehicle in scale.

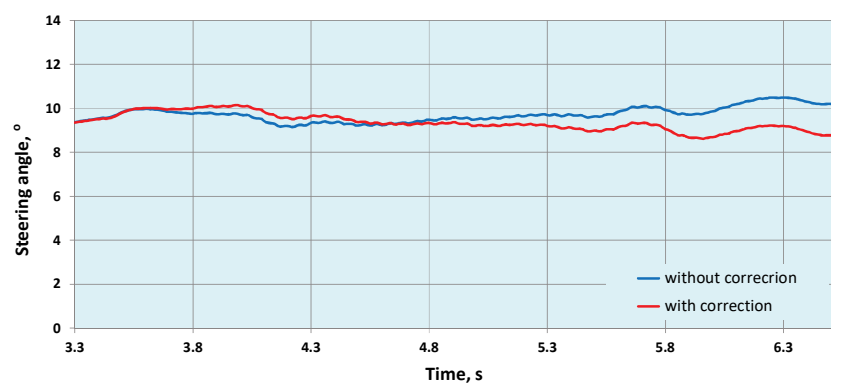

Fig. 6. Steering angle: real and corrected, during the test "ride on a circular path"

The use of a simplified driver model allows for an trajectory adjustment which simulates the behavior of the human driver. Figure 7 shows the realized path, after which vehicle in scale was driving and simulated circular path after correction of steer angle.

Due to accept the simple model of the human driver, the proposed adjustment does not take into account the delayed reaction time of the vehicle to changes in the controller settings. This influence should also be estimated and included in the amendment of control parameters vehicle.

\section{Summary and conclusions}

In this article was presented the preliminary considerations regarding the possibility of construction an autonomous vehicle based on a testing of the vehicle in scale. In such a vehicle may be tested solutions used subsequently in the autonomous vehicle. This article presents possible to use human driver models allowing moving along a specified route or making some adjustments of motion direction 
of the vehicle. Studies were carried out using a vehicle in the scale of $1: 5$.

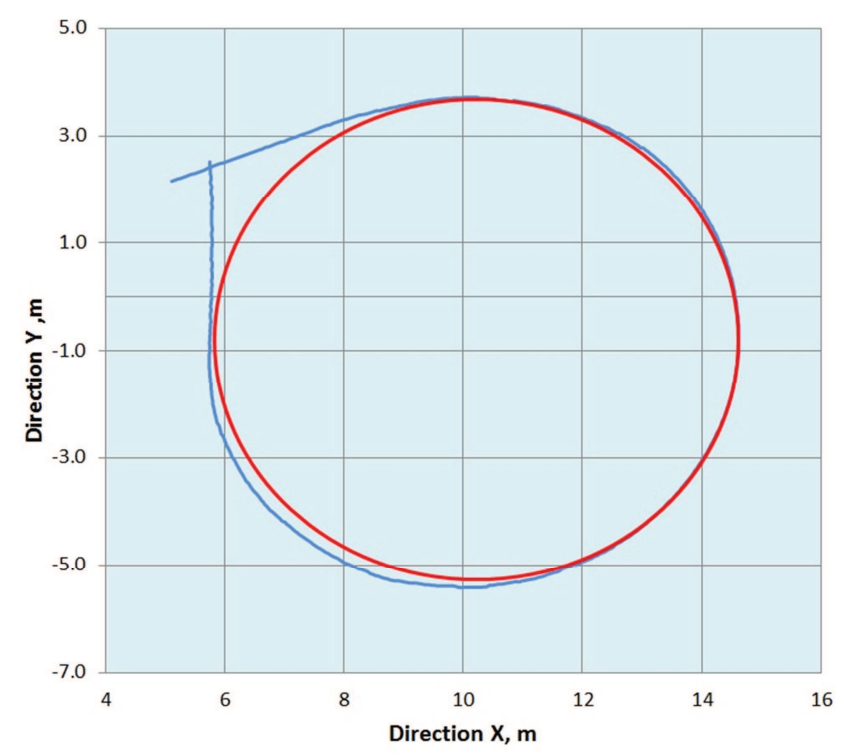

Fig. 7. The vehicle path: real (from the test) and corrected, during the test "ride on a circular path"
The control system based on the position signals from the GPS, which uses a compensation driver model turned out to be little accurate, due to the low frequency determining vehicle position and relatively slow actuators. However, the use of the more efficient measuring apparatus may allow to increase the accuracy of control of the vehicle and eventually to apply it to the autonomous vehicle.

The use of anticipatory model of human driver allows you to make adjustments to the track of the vehicle. From the simulations carried out using the results of measurements made while driving in a circular path indicates that the majority of motion parameters of the vehicle requires filtering with low-pass filter frequency to $6 \mathrm{~Hz}$. The application of the proposed solution requires the use of actuators with a short response time. Delays resulting from the reaction speed of actuators require estimating and taking into account in the applicable adjustment of control parameters.

Ultimately, the planned modifications to the vehicle in scale by incorporating a system of speed control and steer angle with greater accuracy and speed of execution.

Despite this, the authors believe that the results of both of the tests are promising and believe that further research in this area is justified.

\section{Bibliography}

[1] ABE, M. Vehicle handling dynamics. Theory and application, II ed. Elsevier, Oxford 2015, 281-300.

[2] AUGUSTYNOWICZ, A. Modelowanie typu kierowcy samochodu. Wydawnictwo Politechniki Opolskiej. Opole 2009.

[3] BAKER, W.E., EESTINE, P.S., DODGE, F.T. Similarity methods in engineering dynamics. Theory and practice of scale modeling, Spartan Books. New Jersey 1978.

[4] BOGUSZ, M., BIELENIN, D. Projekt i badanie autonomicznego system sterowania do modelu pojazdu. $V$ Konferencja Inżynier XXI w. Bielsko-Biała. 2016.

[5] BUCKINGHAM, E. On physically similar systems: Illustration of the use of dimensional equations. Physics Review. 1914, 4, 345-376.

[6] BUŁKA, D., WALCZAK, S., WOLAK, S. Antycypacyjny model kierowcy zastosowany w programie do symulacji ruchu i zderzeń pojazdów V-Sim. V Konferencja „Problemy bezpieczeństwa w pojazdach samochodowych". Kielce 2006.

[7] KROMULSKI, J., SZCZEPANIAK, J., PAWŁOWSKI, T. Model układu sterowania ze sprzężeniem zwrotnym (człowiek-agregat rolniczy) w aspekcie bezpieczeństwa ruchu. Journal of Research and Applications in Agricultural Engineering. 2011, 56(2), 101-104.

[8] LOZIA, Z. Analiza ruchu samochodu dwuosiowego na tle modelowania jego dynamiki. Monografia. Prace Naukowe Politechniki Warszawskiej. Transport, 1998, 41.

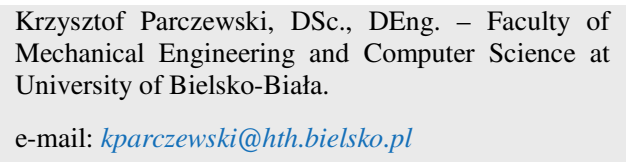

[9] MACADAM, C.C. Understanding and modeling the human driver. Vehicle System Dynamics. 2003, 40(1-3), 101-134.

[10] PARCZEWSKI, K., ROMANISZYN, K.M. Układy kierowania mobilnych modeli pojazdów wykorzystywanych do badań dynamiki ruchu pojazdów. Logistyka. 2015, 4, 789800.

[11] PARCZEWSKI, K. Analiza możliwości wykorzystania modelu fizycznego pojazdu do oceny stateczności ruchu pojazdów wielkogabarytowych. Wydawnictwo Akademii Techniczno-Humanistycznej w Bielsku-Białej. Rozprawa naukowa 52, Bielsko-Biała 2014.

[12] PROCHOWSKI, L. Mechanika ruchu. WKE, Warszawa, 2005, 289-291.

[13] REŃSKI, A. Identification of driver model parameters. International Journal of Occupational Safety and Ergonomics. 2001, 7(1), 79-92.

[14] ROMANISZYN, K.M., WNĘK, H. Symulacja dynamiki ruchu na mobilnym modelu samochodu. Pomiary $A u$ tomatyka Kontrola. 2010, 3, 240-243.

[15] STAŃCZYK, T.L., JURECKI, R. Modele kierowcy, możliwość ich wykorzystania do analizy sytuacji przedwypadkowych. IV Konferencja „Problemy bezpieczeństwa w pojazdach samochodowych”. Kielce 2004.

[16] WITAYA, W., PARINYA, W., KRISSADA, C. Scaled vehicle for interactive dynamic simulation. Proceedings of the 2008 IEEE International Conference on Robotics and Biomimetic. Bangkok, 21-26.02.2009.

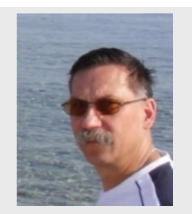

Prof. Kazimierz Romaniszyn, DSc, DEng. - Faculty of Mechanical Engineering and Computer Science at University of Bielsko-Biała.

e-mail:kromaniszyn@ath.bielsko.pl 